\section{Cardiovascular risk index and adequate nutrition}

\section{Índice de riesgo cardiovascular y nutrición adecuada}

To the Editor: We have appreciated some articles about cardiovascular risk factors published in Revista Médica de Chile and would like to address comments about the most recent, from Dr. Tomás Romero ${ }^{1}$. This author discussed the modifiable factors, with focus on the need of real improvement in the socioeconomic features involved in the actual epidemic of obesity. He analyses the actual conundrum linking diverse risk factors and the development of atherosclerosis, and proposes more advantageous risk-benefit and cost-effective measures. ${ }^{1}$ Indeed, cardiovascular disease constitutes a major cause of death in the whole world; main risk factors are sedentary life, excess of weight, arterial hypertension, and dyslipidemia ${ }^{1,2}$. Several studies developed in South American countries emphasize the frequency of obesity and arterial hypertension among schoolchildren and young individuals ${ }^{2-4}$, and call the attention to a correlated increase in the frequency of cardiovascular disorders. Inadequate lifestyle, which includes non-balanced diets (high in salt, poor in fibers and in monounsaturated fats, and rich in cholesterol, saturated and trans fats), is a main risk factor for cardiovascular diseases ${ }^{5,6}$. The purpose of the present comments is to exemplify the favorable effect of a well-balanced diet in common disorders, which may affect South American patients of diverse age groups. A 68 year-old female with antecedent of metabolic syndrome, type 2 diabetes, coronary disease, arterial hypertension and autoimmune hepatitis, was admitted because of cholestasis. She was in use of NPH insulin, acetylsalicylic acid, spironolactone, furosemide, and diltiazem. Her previous diet was considered inadequate; although weight loss was obtained, she persisted with high cardiovascular risk index. Since one year ago, her physical activities became limited due to deterioration in the cardiac function. She denied tobacco smoking and alcoholism. Alimentary inquiry revealed usual low salt diet, low ingestion of regulator foods; and appropriate consumption of energy and bodybuilder foods. Physical examination showed jaundice; waist circumference: $88 \mathrm{~cm}$; and BMI: $23.62 \mathrm{~kg} / \mathrm{m}^{2}$; other data were unremarkable. La- boratory determinations (Table 1) revealed liver changes and elevated cardiovascular risk (Castelli index). Thyroid function tests and ultrasensitive C-reactive protein were normal. Recent nutritional management consisted of a diet low in salt and in fats, and without sucrose. The diet contained 1800 $\mathrm{kcal}(27.6 \mathrm{kcal} / \mathrm{kg})$, with foods rich in omega-3 and omega-9 fatty acids, including linseed $(50 \mathrm{~g} /$ day), olive oil (40ml/day) and oleaginous fruits $(30 \mathrm{~g} /$ day $)$. Additionally, diverse fresh fruits were included in her six daily meals. Less than a month under dietary control, the HDL level rose from 6 to $27 \mathrm{mg} / \mathrm{dl}$ and triglycerides decreased from 153 to $133 \mathrm{mg} / \mathrm{dl}$, lowering the Castelli index. After clinical improvement and following adequate diet, she was referred to longstanding outpatient nutritional surveillance.

Good alimentary habits play an important role in the general health and in quality of life. Adequate consumption of foods rich in omega- 3 polyunsaturated fatty acids (PUFA) as oils (flaxseed, linseed, canola, walnut, wheat germ, and soybean), green leafy vegetables, legumes, fresh fruits, and cold water fish; omega-6 PUFA (vegetable oils) and omega-9 PUFA (olive oil and oleaginous fruits) can contribute to reduce cardiovascular diseases $^{5,6}$. Normalization of lipid profile is beneficial for patients with heart arrhythmias, reduces inflammatory processes, shows anti-thrombotic and anti-atherosclerotic effects; and can play an important role in the management of the metabolic syndrome $e^{2,5,6}$. Correction of inadequate diet habits can prevent and control cardiovascular diseases, which emphasizes the need for adequate nutritional education ${ }^{1,5}$. Each elevation of $1 \mathrm{mg} /$ $\mathrm{dl}$ in plasma HDL reduces in 6\% the risk of death due to coronary disease ${ }^{5}$; in addition, there is a decrease in hypertriglyceridemia, which constitutes a cardiovascular risk factor. Light and moderate physical exercises contribute to increase the HDL level; and, if necessary, some hypolipidemic drug should be associated ${ }^{5}$. Adequate nutritional therapy heightened plasma levels of the HDL fraction, with reduction of the Castelli cardiovascular risk index, and contributed to normalize the plasma lipid profile of this elderly female with arterial hypertension and diabetes mellitus. Coronary disease and hypertension contributed to sedentary habits, with difficulties to control her dyslipidemia, not associated with overweight. In fact, this elderly patient obtained benefits from a well-balanced 
Table 1. Blood parameters from a 68-year-old female with adequate diet to reduce the Castelli risk index

\begin{tabular}{|c|c|c|c|c|c|c|c|}
\hline Parameters (2009) & $\begin{array}{c}\text { May } \\
15\end{array}$ & $\begin{array}{c}\text { May } \\
24\end{array}$ & $\begin{array}{c}\text { June } \\
05\end{array}$ & Parameters (2009) & $\begin{array}{c}\text { May } \\
08\end{array}$ & $\begin{array}{c}\text { May } \\
13\end{array}$ & $\begin{array}{c}\text { June } \\
05\end{array}$ \\
\hline Cholesterol (mg/dl) & 179 & 131 & 145 & Total bilirubin (mg/dl) & 13.60 & 5.50 & 2.30 \\
\hline LDL (mg/dl) & 87 & 89 & 91 & Direct bilirubin (mg/dl) & 9.88 & 4.05 & 1.64 \\
\hline $\mathrm{HDL}(\mathrm{mg} / \mathrm{dl})$ & 6 & 12 & 27 & AST (U/dl) & 460.4 & 505.1 & 76.6 \\
\hline VLDL (mg/dl) & 31 & 30 & 27 & $\operatorname{ALT}(\mathrm{U} / \mathrm{dl})$ & 467.8 & 475.1 & 75.9 \\
\hline Tryglicerides (mg/dl) & 153 & 151 & 133 & Gamma GT (U/dl) & 527.3 & 513.6 & 433.6 \\
\hline Cl 1 (normal: < 4.4) & 20.7 & 10.9 & 5.4 & Alkaline phosfatases (U/dl) & 104.7 & 104.6 & 129.8 \\
\hline Cl 2 (normal: < 2.9) & 14.6 & 7.4 & 3.4 & Prothrombin activity (\%) & 36 & 46 & 45 \\
\hline Glucose (mg/dl) & 85 & 94 & 217 & INR & 1.93 & 1.57 & 1.59 \\
\hline Urea (mg/dl) & 19 & 22.5 & 22.9 & Albumin (mg/dl) & 3.5 & 3.5 & 3.6 \\
\hline Creatinine (MG/dl) & 0.6 & 0.6 & 0.7 & LDH (U/dl) & 444 & ND & ND \\
\hline
\end{tabular}

Cl: Castelli risk index; ND: not done.

diet in a very short time, and actually, her lipid parameters are within normal range, as well as the Castelli index. Nevertheless, more effective results should be achieved by "modifying the modifiable cardiovascular risk factors", ${ }^{1}$ as soon as possible. For instance, by adopting adequate diets and good lifestyle habits since early infancy, and maintaining them during all the life-course. While "public and privately sponsored mechanisms to improve education and access to health resources" are not entirely available to populations from developing countries, the authors believe that this is an "advantageous risk-benefit and cost-effective strategy" to be followed ${ }^{1}$.

Vitorino Modesto dos Santos, $M D, P h D^{1,2}$, Liliane Aparecida Soares, $M D^{2}$, Suelma de Carvalho Santos, $\mathrm{MD}^{2}$ ${ }^{1}$ Catholic University Medical Course ${ }^{2}$ Department of Internal Medicine from Armed Forces Hospital (HFA), Brasília-DF, Brazil

\section{References}

1. Romero T. Factores modificables de riesgo cardiovascular: ¿Cuáles estamos realmente modificando? Rev Med Chile 2009; 137: 1498-501.

2. Barja S, Acevedo M, Arnaiz P, Berríos X, Bambs C, Guzmán $\mathrm{B}$, et al. Marcadores de aterosclerosis temprana y síndrome metabólico en niños. Rev Med Chile 2009; 137: 522-30

3. Loaiza MS, Taibo GM, Cornejo A, Atalah E. Evolución del estado nutricional en una cohorte de escolares chilenos: ¿Un cambio real o ficticio? Rev Med Chile 2009; 137: 1149-56.

4. Xavier MM, Xavier RM, Magalhães FO, Nunes AA, Santos VM. Fatores associados à prevalência de obesidade infantil em escolares. Ped Moderna 2009; 45: 105-8.

5. Alfonso JEF, Ariza IDS. Elevando el colesterol HDL: ¿Cuál es la mejor estrategia? Rev Assoc Med Bras 2008; 54: 369-76.

6. Dimitrow PP, Jawien M. Pleiotropic, cardioprotective effects of omega-3 polyunsaturated fatty acids. Mini Rev Med Chem 2009; 9: 1030-39.

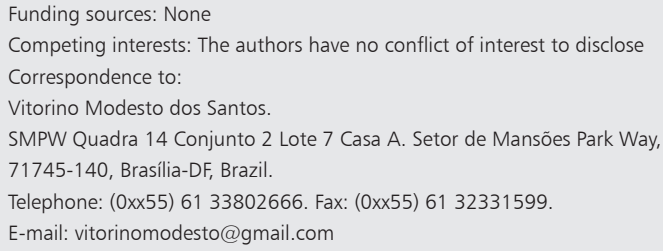

